\title{
Apresentação: Totalitarismo, Democracia e Populismo na América Latina
}

Franz Josef Brüseke

Carlos Eduardo Sell ${ }^{2}$

A América Latina, que despontava no limiar do século XXI com uma grande esperança de desenvolvimento econômico e democratização política, encontra-se hoje profundamente dividida, com fortes sinais de retrocesso. A ressurgência da tradição populista, tanto no seu aspecto político carismático autoritário, quanto na sua dimensão econômica centralista e estatista, presente de diferentes formas e intensidades nas diversas regiões e países, coloca um desafio para as vertentes teóricas hoje hegemônicas no campo da ciência política e da sociologia. Atualmente, a compreensão crítica deste processo ficou dificultada porque a narrativa predominante na ciência política apostou de forma excessivamente otimista na consolidação das instituições políticas convencionais, ignorando os novos e velhos entraves deste processo. Por outro lado, o tema da democracia, bem como a temática do populismo, também se acham silenciadas por teorizações que, com um viés abertamente ideológico (pós-neoliberalismo), propugnam a apologia e a legitimação destes regimes.

Diante deste cenário, a Revista Tomo apresenta um dossiê que busca refletir, tanto teórica quanto empiricamente, sobre os regimes políticos da América Latina à luz dos conceitos de totalitarismo, democracia e populismo. 0 que se buscou são trabalhos da sociologia e da ciência política que, levando em consideração a peculiaridade da América Latina no quadro da modernidade, captem as dinâmicas sociais e políticas em curso, descrevendo os desafios institucionais que atravessam as culturas e sociedades deste continente.

\footnotetext{
${ }^{1}$ Universidade Federal de Sergipe, pesquisador do CNPq.

${ }^{2}$ Universidade Federal de Santa Catarina, pesquisador do CNPq.
} 
Na sua contribuição para esta reflexão, Carlos Eduardo Sell convida para reconsiderar um conceito frequentemente empregado quando se trata de analisar América Latina, o populismo. Apesar da recorrência e persistência do fenômeno do populismo na América Latina, a discussão sobre esta categoria tem estado ausente do centro das atuais análises acadêmicas feitas no Brasil. Indo além das análises clássicas que, a partir do enfoque nas classes, priorizam, de forma unilateral, seus componentes estruturais, o artigo revisa o debate sobre o carisma na teoria política de linha weberiana, propondo definir o populismo como um subtipo da dominação carismática.

Por este ângulo, enfatiza-se a dimensão especificamente política do populismo, apontando o caráter carismático necessariamente presente na relação emocional entre líder e povo. Com base nesta premissa, sugere-se ainda um modelo para a compreensão do populismo segundo os diferentes níveis de manifestação do fenômeno: sociocultural (histórico-latente), institucional (tipo de regime) e psicossocial (estilo de liderança).

Descendo da reflexão teórica para a história real, vivida como ator e testemunho, Héctor Leis toma como material de análise suas próprias memórias e reflete no seu artigo sobre os vínculos analíticos e empíricos entre os fenômenos da revolução, da guerrilha e do terrorismo. A análise das práticas e de concepções de grupos guerrilheiros urbanos da América Latina, em especial dos Montoneros, na Argentina, mostra que o terrorismo estava no centro das estratégias políticas deste grupo desde o seu início. Ao final, rejeita-se o dualismo entre práticas terroristas advindas da sociedade civil ou do Estado e que penaliza apenas este segundo segmento, argumentando-se que ambas foram exercidas contra o conjunto da Comunidade Política. Por esta razão, todos aqueles que colaboraram de uma ou outra maneira se converteram em cúmplices, na avaliação do autor. 
Daniel Chaves de Brito continua com a reflexão sobre a violência, desta vez do ângulo brasileiro, e analisa de um lado a formação do sistema brasileiro de justiça criminal, principalmente as polícias, como elemento importante da estabilização da ordem, tendo por base o longo predomínio do autoritarismo e do populismo, que delineiam os instrumentos estatais de controle social e marcam profundamente a formação da cidadania. Por outro, tenta refletir sobre as políticas de segurança pública e perspectiva da democracia, mostrando uma impermeabilidade ao processo de modernização no que tange à absorção dos princípios da racionalidade impessoal. Apresenta-se em primeiro lugar uma analise histórica entre o processo de modernização, a formação da cidadania e o instrumento da violência como mediação legal entre a sociedade e o Estado. Em segundo, destaca-se uma relação entre as concepções teóricas do policiamento e suas ambiguidades na concepção dos planos de segurança pública.

Bolivar Lamounier contribui com um texto escrito no calor dos debates sobre as manifestações de Junho de 2013 e delineia três correntes de pensamento que permeiam o debate público brasileiro: as utopias da intervenção militar, da democracia 'direta' e a de uma democracia representativa, fortemente idealizada. Não poderiam faltar, no final, algumas considerações de ordem geral sobre a reforma política e o sistema eleitoral no Brasil.

Para dar sustentação macro-sociológica a um dossiê tão rico em perspectivas divergentes, convida Franz Josef Brüseke a um debate acerca do "projeto de melhorar o homem", que tende em tempos da modernização técnica a contribuir de forma bem particular para processos totalitários. 
